\title{
Characterization and selection of torch ginger for cut flower ${ }^{(1)}$
}

\author{
PAULA GUIMARÃES PINHEIRO DE ARAÚJO(2), JOÃO CARLOS CÉSAR DE ALBUQUERQUE FILHO(3), \\ SIMONE SANTOS LIRA SILVA(3), CARLOS EDUARDO FERREIRA DE CASTRO(4), \\ CHARLESTON GONÇALVES ${ }^{(4)}$, VIVIAN LOGES ${ }^{(3)^{*}}$
}

\begin{abstract}
Torch ginger, Etlingera elatior, is among the most cultivated tropical flower of its genus. Its great acceptability in the market led researchers to improve production characteristics and to adapt it for commercialization. This study aimed to characterize 10 genotypes of torch ginger in order to select and recommend them as cut flower. The experiment ran from Jan 2014 to Dec 2016 in Paulista, Brazil and nine agro-morphological characteristics were evaluated to build a grading system that determined their suitability for cut flower. The IAC 26 and IAC 34 genotypes were classified as poorly suitable, for they presented fresh mass exceeding $237 \mathrm{~g}$. They also presented less than 19 flower stems per clump and only one month with $\geq 1$ floral stem produced in 2015. The genotypes IAC 1, IAC 2, IAC 3, IAC 11, IAC 13 and the cultivar IAC Prumirim were classified as suitable, although they obtained intermediate scores for most of the evaluated criteria. The genotype IAC 41 and the cultivar IAC Camburi were classified as very suitable for cut flower, beginning of flowering period at 12 months, produce 33.25 and 41.20 flower stem per clump, respectively, and present seven months with production of more than one floral stem per clump in 2016, achieving maximum scores from most of the evaluated characteristics.
\end{abstract}

Keywords: Etlingera elatior, tropical flowers, production.

\section{RESUMO}

\section{Caracterização e seleção de bastão-do-imperador para flor de corte}

Bastão-do-imperador, Etlingera elatior, é a espécie mais cultivada de flores tropicais do gênero. A sua aceitabilidade no mercado levou os pesquisadores a melhorarem características de produção e adequá-las para a comercialização. Esta pesquisa tem por objetivo caracterizar 10 genótipos de bastão do imperador para seleção e recomendação como flor de corte. O experimento foi conduzido de janeiro de 2014 a dezembro de 2016 em Paulista, Brasil. Foram avaliados nove características morfoagronômicos para classificar e determinar a adequação para a flor de corte. IAC 26 e IAC 34 foram classificados como pouco adequados, com massa fresca superior $237 \mathrm{~g}$, número de hastes florais inferior a 19 por touceira e apenas um mês com produção de uma ou mais hastes florais em 2015. Os genótipos IAC 1, IAC 2, IAC 3, IAC 11, IAC 13 e a cultivar IAC Prumirim foram classificados como adequados, embora tenham obtido pontuação intermediária para a maioria dos critérios avaliados. Os genótipos IAC 41 e a cultivar IAC Camburi foram classificados como muito adequados para flor de corte, inciando o período de florescimento aos 12 meses, produzindo 33,25 a 41,20 hastes florais por touceiras, respectivamente, e apresentaram sete meses com produção de mais de uma hastes floral por touceira em 2016, alcançando maxima pontuação para a maioria dos caracteres avaliados.

Palavras-chave: Etlingera elatior, flores tropicais e produção.

\section{INTRODUCTION}

The increasing consumer demand for versatility, durability and low cost of flowers in the last few years, has made markets constantly seek out for new products. Thereby, new varieties are constantly introduced into the flower market every year, contributing to its renewal.

Several steps are required to obtain and recommend improved genotypes. The conservation, characterization, evaluation and records of germplasm banks are essential steps that may not be underestimated (NASS and PATERNIANI, 2000). Those are essential stages for germplasm classification and utilization, as they allow the identification of promising cultivars that either can integrate breeding programs or be validated by farmers for cultivation.

Among the tropical flowers, Etlingera elatior (Jack) R. M. Smith is the most cultivated species of the genus Etlingera, and popularly known as torch ginger. It is an herbaceous, perennial, and rhizomatous plant that belongs to the Zingiberaceae family. The clumps are vigorous, with the emission of vegetative and floral stems in the periphery and in the center of the clump. The inflorescences show colors that vary from red and pink to white, which grow

\footnotetext{
DOI: http://dx.doi.org/10.14295/oh.v24i4.1207

(1) Received in 15/05/2018 and accepted in 20/09/2018

(2) Instituto Federal de Pernambuco, Campus Vitória de Santo Antão/IFPE, Vitória de Santo Antão-PE, Brazil.

(3) Universidade Federal Rural de Pernambuco (UFRPE), Recife-PE, Brazil. *Corresponding author: vloges@yahoo.com

(4) Instituto Agronômico (IAC), Centro de Horticultura, Campinas-SP, Brazil.

Licensed by CC BY 4.0
} 
directly from the rhizomes (LOGES et al., 2008b). It is a species used for many purposes such as culinary, medicinal, essential oil extract, and ornamental (CHAN et al., 2011; CHOON and DING, 2016).

In Brazil, Pernambuco state in the Northeast region stands out for the cultivation of white, red, and pink torch ginger to be used as cut flower (LOGES et al., 2008b). However, inadequate characteristics, i.e. low productivity, seasonality, large and heavy flower stems, and low durability were observed in some genotypes, deeming necessary to conduct further screening for suitable species and cultivars to the market.

Hoult and Marcsik (2000) in Australia evaluated four cultivars of torch ginger that produced from 50 to 200 flower stems per clump, with post-harvest durability ranging from 3 to 10 days. Gonçalves et al. (2014) performed the agromorphological and molecular characterization of 75 halfsiblings of torch ginger from the germplasm collection of the Agronomic Institute (IAC, Brazil), and observe a high genetic diversity. In 2015, the cultivars IAC Prumirim, IAC Itamambuca, IAC Camburi, and IAC Cacheffo (E. elatior $x$ $E$. haemespherica) were introduced to the Brazilian flower market. These cultivars have post-harvest durability, shape and weight that allow greater efficiency during transport and commercialization (GONÇALVES et al., 2015).

It is important to analyze the environmental adaptability and market fit of genotypes or new cultivars by regional field testing. This study aimed to characterize ten torch ginger genotypes and to select the most suitable for cultivation as cut flower.

\section{MATERIAL AND METHODS}

The experiment was carried out between January 2014 and December 2016 in Paulista, in the so-called Zona da Mata of Pernambuco State, Brazil (located at $08^{\circ} 01^{\prime} 19$ ', South, 3459' 33" West, at 100 a.s.1.). The region presents a tropical climate (Am') according to the classification of Köppen's (ALVARES et al., 2013). The monthly temperature, precipitation, and relative humidity data were obtained from the National Institute of Meteorology (Figure 1). The photoperiod or effective period was the number of hours of sun exposure of the experimental area during the 24-hour period (VAREJÃO-SILVA, 2006).
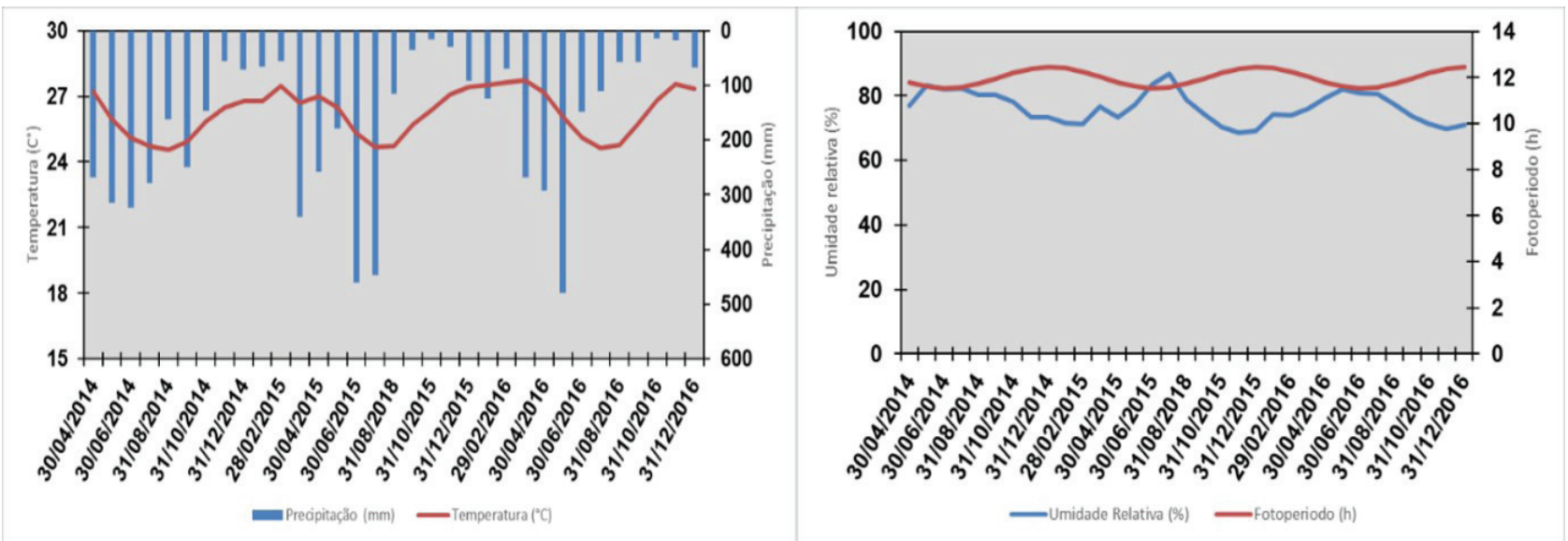

Figure 1. Precipitation, temperature, relative humidity, and photoperiod from January 2014 to December 2016.

Ten half-siblings genotypes of torch ginger (Figure 2) originated from a random cross-section from the Germplasm Collection of the Agronomic Institute, were evaluated. In January 2014, rhizomes bearing $20 \mathrm{~cm}$ of pseudostem of eight pre-selected genotypes IAC 1, IAC 2 ,
IAC 3, IAC 11, IAC 13, IAC 26, IAC 34, and IAC 41) and two cultivars (IAC Prumirim and IAC Camburi) registered in SNPC-MAPA-Brazil, were cleaned, submitted to the regular disease and pests control treatment, and planted in beds for rooting. 


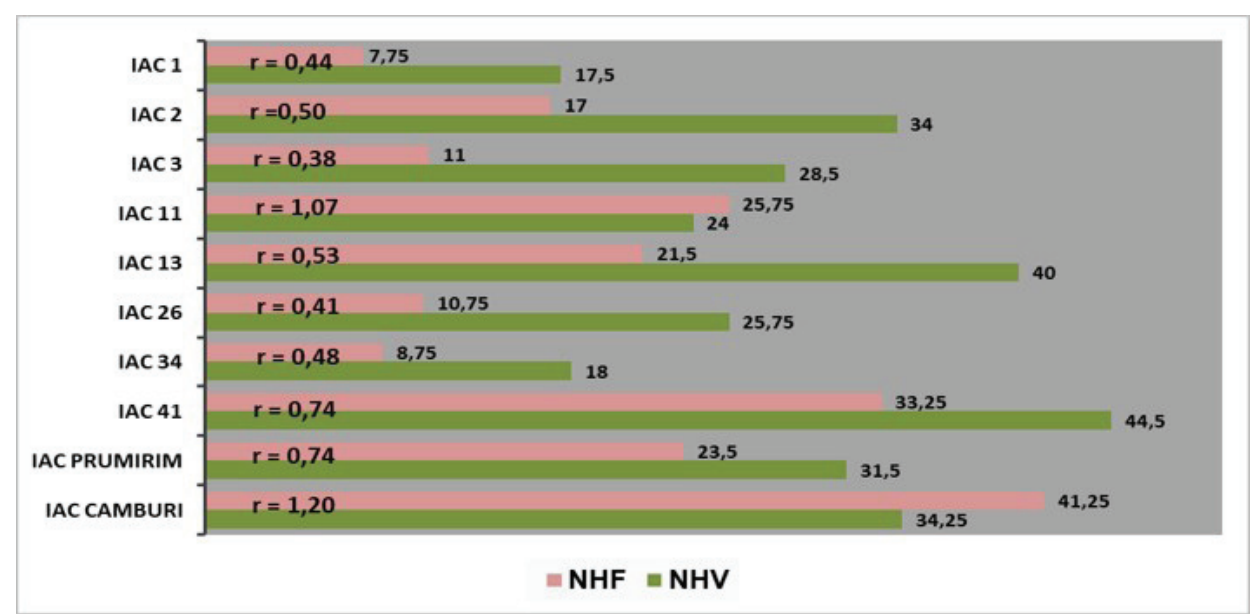

Figure 2. Genotypes of the Etlingera elatior, cultivated in half-shade.

In April 2014, four clumps (the rhizome with roots and new shots) were transplanted in randomized blocks to the experimental area, spaced by $1.5 \times 1.5 \mathrm{~m}$. The area was partially shaded by trees, with a high sprinkler irrigation system used in alternate days, except on rainy days. Local agricultural practices were adopted and the clump was fertilized with NPK $(200 \mathrm{~g})$ and organic compost $(1 \mathrm{Kg})$ each three months.

As like in May 2014, the clumps were periodically evaluated for the following characteristics: $\mathrm{BF}$ - beginning of flowering; NFS - number of floral stems per month in the clump; and NVS - number of vegetative stems per month. The vegetative stems, that present conical shape with the upper part pointed, and the floral stems, that was more cylindrical shape, were marked at $8 \mathrm{~cm}$. The ratio (r) between the NVS and the NFS emitted three months later, period necessary for the emission of the floral stem after the emission of the vegetative stem was calculated. All inflorescence flower stems were harvested closed (base bracts closed), semi-open (base bracts beginning to open and central part of the inflorescence visible) or open (base bracts completely open and flower opening). From the data collected, the development period from the emission of the floral stem to the harvest (CYCLE) was obtained.

The flower stems were evaluated for: IW - inflorescence width, measured in the largest part of the inflorescence; IL - inflorescence length, from the base of the inflorescence to its apex; SL - floral stem length, distance from the base of the pseudostem to the inflorescence apex; SD - floral stem diameter, measured $20 \mathrm{~cm}$ below the inflorescence; FM - fresh mass with the floral stem length standardized at $80 \mathrm{~cm}$; and PHD - postharvest durability of semi-open inflorescences. For the evaluation of PHD, the floral stems were placed in containers with tap water and evaluated every two days. They were discarded when signs of senescence, such as darkened and dried edges of the bracts, were observed. The storage conditions were constant at 25 ${ }^{\circ} \mathrm{C}$ with relative humidity approx. $77 \%$.

Following the score to the agro-morphological characteristics (Table 1), the genotypes were classified for cut flower use as: Very suitable - score $\geq 27$; Suitable - score between 22 to 26; Poorly suitable - score $\leq 21$.

For the analysis of the NFS data, the plot was subdivided in time (plot being the genotype and the time as subplot). The NFS data was grouped by semester starting in January 2015, beginning of the flowering period: $1^{\text {st }}$ semester - from 13 to 18 months after planting (MAP); $2^{\text {nd }}$ semester - from 19 to $24 \mathrm{MAP} ; 3^{\text {rd }}$ semester - from 24 to $30 \mathrm{MAP}$; and $4^{\text {th }}$ semester - from 31 to 36 MAP. The Scott-Knott clustering and Tukey tests were used, both at $5 \%$ probability, using the Sisvar software version 5.7 (Build 77). For the variables LI, WI, LS, DS, MF, CYCLE, and PHD, the $4^{\text {th }}$ semester data were used with the randomized block scheme using Tukey test, $5 \%$ probability, with the Genes program VS 2013.5.1 (CRUZ, 2013). 
Table 1. Score to agro-morphological characteristics of E. elatior for cut flower use (adapted from GONÇALVES et al., 2014).

\begin{tabular}{|c|c|c|c|}
\hline \multirow{2}{*}{ Characteristics } & \multicolumn{4}{|c|}{ Score } \\
\hline IL & $\mathbf{1}$ & $\mathbf{2}$ & $\mathbf{3}$ \\
\hline IW & - & $\leq 11 \mathrm{ou} \geq 16$ & 12 a 15 \\
\hline SL & - & $\leq 13 \mathrm{ou} \geq 18$ & 14 a 17 \\
\hline SD & - & $\leq 99$ ou $\geq 129$ & 100 a 128 \\
\hline FM & - & $\leq 0.90$ ou $\geq 1.66$ & 1.00 a 1.65 \\
\hline CYCLE & - & $\geq 237$ & 166 a 236 \\
\hline PHD & $\geq 60$ & 41 a 59 & $\leq 40$ \\
\hline BF & $\leq 3$ & 4 a 6 & $\geq 7$ \\
\hline NFS & $\geq 19$ & 13 a 18 & $\leq 12$ \\
\hline MP for 2015 and 2016 & $\leq 19$ & 20 a 29 & $\geq 30$ \\
\hline
\end{tabular}

IL - inflorescence length (cm); IW - inflorescence width (cm); SL - floral stem length (cm); SD - floral stem diameter (cm); FM - fresh mass (g); CYCLE - development period from the emission of the floral stem to the harvest (days); PHD - post-harvest durability (days); BF - beginning of the flowering (months); NFS - number of floral stems e MP for 2015 and 2016 - (months with production $\geq 1$ floral stem, per year).

\section{RESULTS AND DISCUSSION}

The experiment highlighted differences between the evaluated genotypes. The agromorphological characteristics led to understand the development of the torch ginger in the period of three years, being possible thus, to select two genotypes for cut flower use in the Zona da Mata of Pernambuco State, Brazil.

The genotypes IAC 1, IAC 3, IAC 11, IAC 13, IAC 26, IAC 41, and the cultivars IAC Prumirim and IAC Camburi stood out with the beginning of the flowering $(\mathrm{BF})$ at 12 months after planting (MAP) (Figure 3). Only IAC 2 and IAC 34 showed BF at thirteen and fourteen MAP, respectively. According to Ribeiro et al. (2012), the torch ginger flowering begins from 12 to 18 MAP. Early flowering genotypes are more indicated, as they provide faster production and harvest; as well as earlier return to the production investments.

It was possible to observe the absence of production in some genotypes in several months of the year. However, there was no evidence of seasonality or influence of the temperature, precipitation, and photoperiod on the yield, once there was no concentration of production in a periodically manner. According to Nascimento et al. (2015), shading in the base of the plant may reduce the development of the floral stem, but those that develop are high quality stems.

The genotypes IAC 1 and IAC 3 presented less than one floral stem in all months of 2015 (Figure 3). The number of flower stems (NFS) per clump was higher in the IAC 41 and IAC Camburi, with more than three flower stems in several months of the year (Figure 3 ). The genotypes IAC 2, IAC 11, IAC 13, IAC 41, and IAC Camburi showed a peak of NFS between November and December 2016. Loges et al. (2008a) observed at the same location that torch ginger red and light pink showed peak of production from September to November 2005. Producers prefer genotypes with high monthly production throughout the year, since demand is equally distributed throughout the year.

Only the cultivar IAC 41 showed a significant difference for NFS over time, with higher production (17.25 NFS) in the fourth semester (Table 2). The genotypes IAC 1, IAC 2, IAC 11, and the cultivars IAC Prumirim and IAC Camburi showed higher production in the second $(2.00,5.50,9.75$, 6.00 and 13.00) and fourth semester $(3.00,6,75,5.75,10.00$ and 12.75). The genotypes IAC 3, IAC 13, and IAC 26 increased production over time. The genotype IAC 34 alone reduced the production in the fourth semester (1.50 NFS), but there was no statistical difference between the genotypes. 
MC I. NIIV X NIF
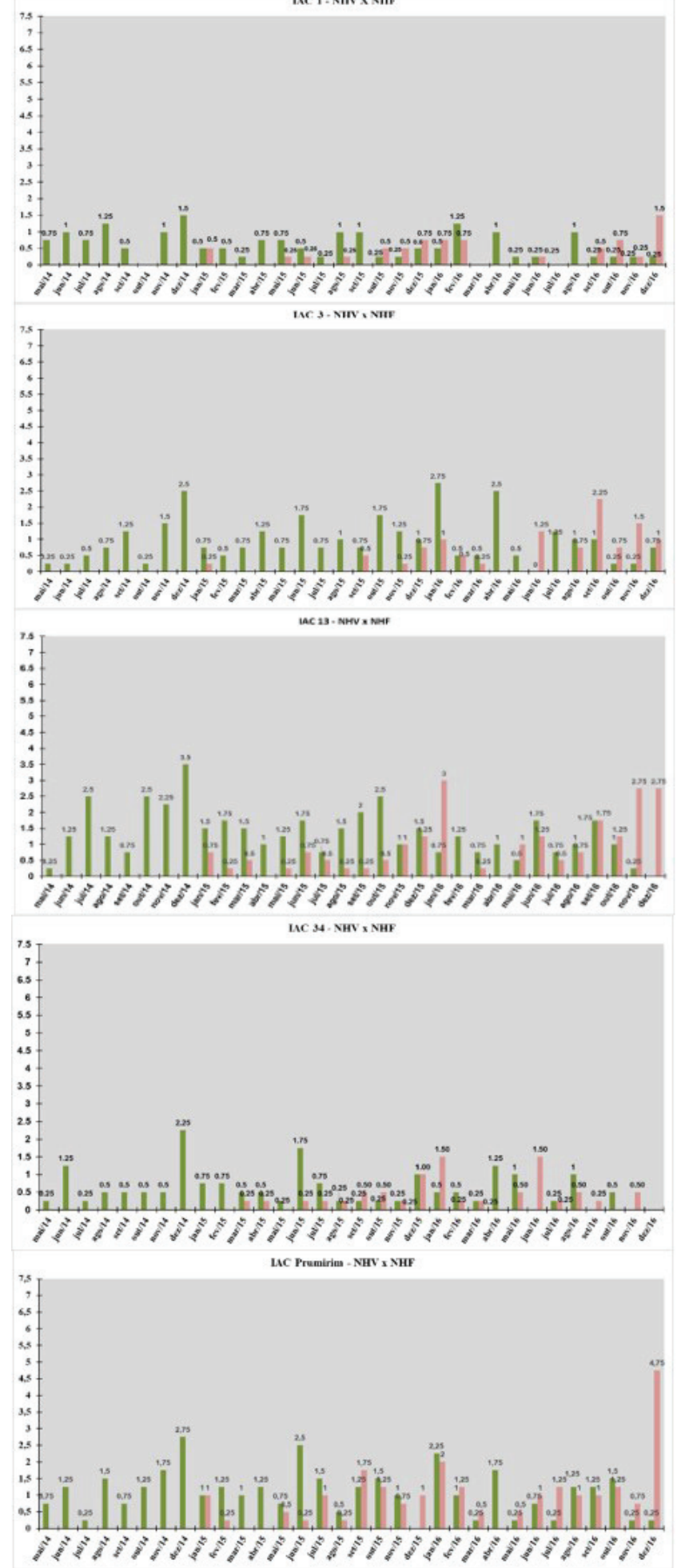

MC 2-NHV $x$ SHF

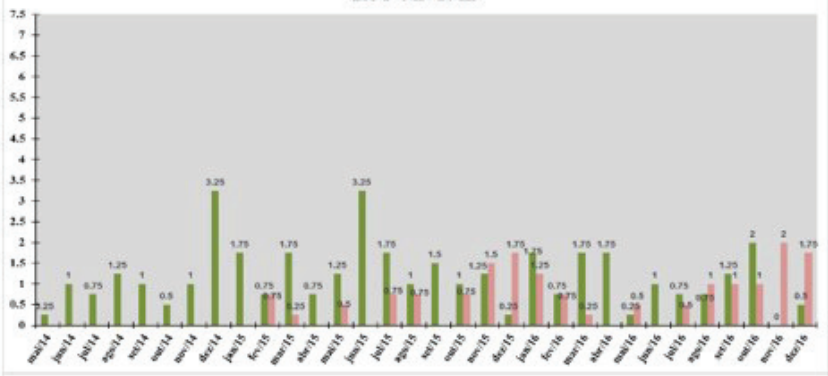

LAC 11 - SHV x NHF
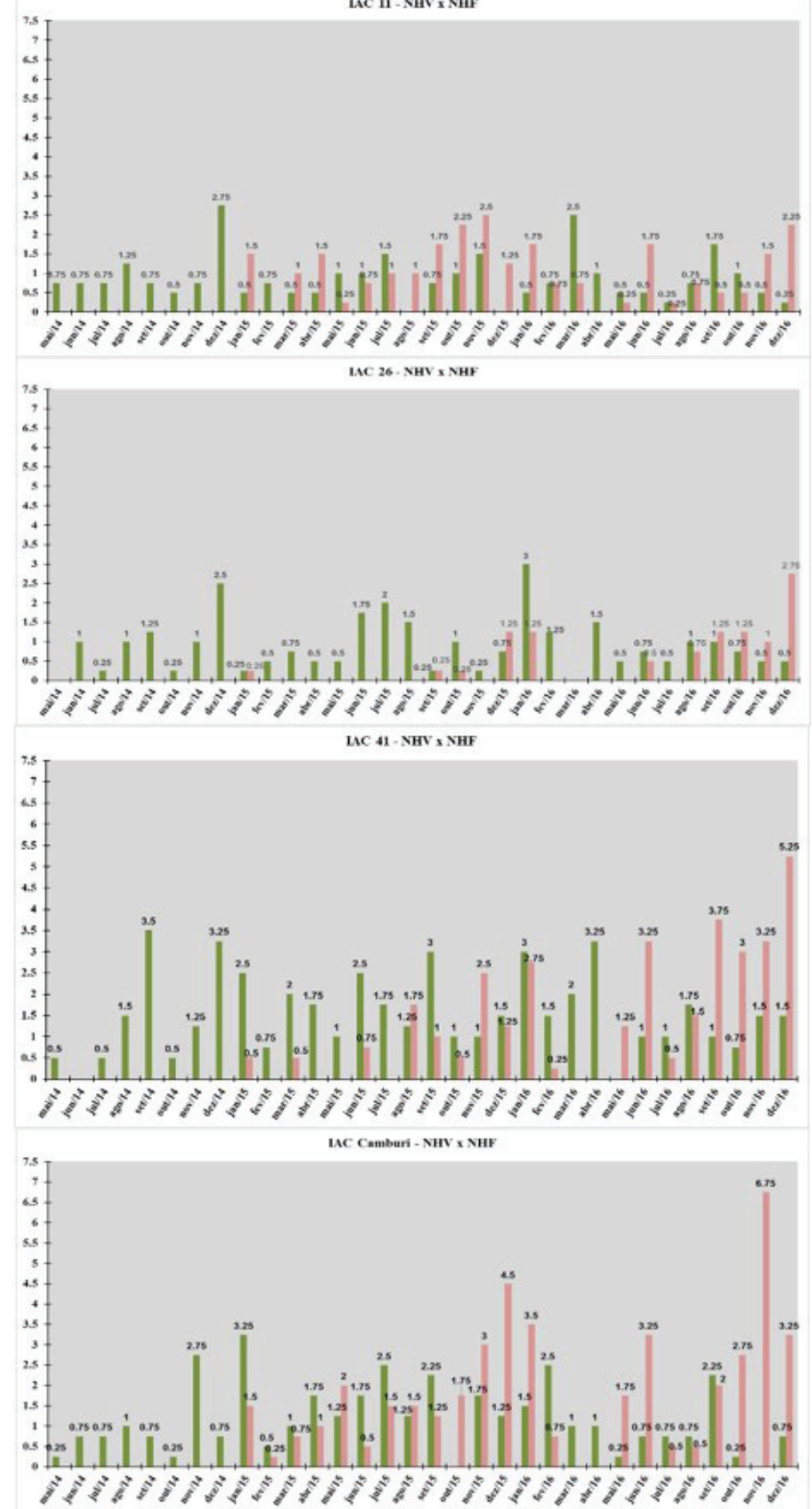

Figure 3. Number of vegetative stems (NVS - green column) and number of floral stems (NFS - pink column) per clump of genotypes Etlingera elatior from May 2014 to December 2016. 
Table 2. Number of floral stems (NFS) per semester in torch ginger genotypes (Etlingera elatior), from January 2015 to December 2016, Paulista-PE.

\begin{tabular}{|c|c|c|c|c|c|c|c|}
\hline Genotypes & $\mathbf{I L}(\mathbf{c m})$ & $\mathbf{I W}(\mathbf{c m})$ & $\mathbf{S L}(\mathbf{c m})$ & $\mathbf{S D}(\mathbf{c m})$ & $\mathbf{F M}(\mathbf{g})$ & $\mathbf{C Y C L E}(\mathbf{d a y})$ & PHD(day) \\
\hline IAC 1 & $7.22 \mathrm{a}$ & $7.31 \mathrm{~b}$ & $79.39 \mathrm{a}$ & $1.08 \mathrm{a}$ & $171.14 \mathrm{a}$ & $52.37 \mathrm{a}$ & $5.00 \mathrm{a}$ \\
\hline IAC 2 & $10.82 \mathrm{a}$ & $13.86 \mathrm{ab}$ & $118.30 \mathrm{a}$ & $1.21 \mathrm{a}$ & $195.36 \mathrm{a}$ & $66.17 \mathrm{a}$ & $6.45 \mathrm{a}$ \\
\hline IAC 3 & $9.36 \mathrm{a}$ & $10.97 \mathrm{ab}$ & $100.28 \mathrm{a}$ & $0.87 \mathrm{a}$ & $147.69 \mathrm{a}$ & $52.28 \mathrm{a}$ & $5.29 \mathrm{a}$ \\
\hline IAC 11 & $7.51 \mathrm{a}$ & $9.47 \mathrm{ab}$ & $87.41 \mathrm{a}$ & $1.05 \mathrm{a}$ & $140.48 \mathrm{a}$ & $69.49 \mathrm{a}$ & $6.10 \mathrm{a}$ \\
\hline IAC 13 & $9.59 \mathrm{a}$ & $12.17 \mathrm{ab}$ & $128.49 \mathrm{a}$ & $1.21 \mathrm{a}$ & $165.25 \mathrm{a}$ & $70.97 \mathrm{a}$ & $7.90 \mathrm{a}$ \\
\hline IAC 26 & $11.18 \mathrm{a}$ & $14.20 \mathrm{ab}$ & $150.59 \mathrm{a}$ & $1.39 \mathrm{a}$ & $248.85 \mathrm{a}$ & $68.59 \mathrm{a}$ & $6.71 \mathrm{a}$ \\
\hline IAC 34 & $8.89 \mathrm{a}$ & $11.59 \mathrm{ab}$ & $116.22 \mathrm{a}$ & $1.35 \mathrm{a}$ & $277.03 \mathrm{a}$ & $59.52 \mathrm{a}$ & $5.93 \mathrm{a}$ \\
\hline IAC 41 & $12.57 \mathrm{a}$ & $15.93 \mathrm{a}$ & $134.59 \mathrm{a}$ & $1.43 \mathrm{a}$ & $273.75 \mathrm{a}$ & $61.16 \mathrm{a}$ & $8.09 \mathrm{a}$ \\
\hline IAC Prumirim & $10.23 \mathrm{a}$ & $11.89 \mathrm{ab}$ & $95.79 \mathrm{a}$ & $1.03 \mathrm{a}$ & $144.35 \mathrm{a}$ & $70.34 \mathrm{a}$ & $4.89 \mathrm{a}$ \\
\hline IAC Camburi & $9.48 \mathrm{a}$ & $11.42 \mathrm{ab}$ & $114.23 \mathrm{a}$ & $1.19 \mathrm{a}$ & $179.09 \mathrm{a}$ & $63.78 \mathrm{a}$ & $5.86 \mathrm{a}$ \\
\hline
\end{tabular}

* Averages followed by the same letter in the column. do not differ from each other. by the Tukey test at the level of $5 \%$

IL - inflorescence length; IW - inflorescence width; SL - floral stem length; SD - floral stem diameter; FM - fresh mass; CYCLE - development period from the emission of the floral stem to the harvest e PHD - post-harvest durability.

The IAC 41 and IAC Camburi flower stem productions stood out ahead of the others during the evaluated period, with 33.25 and 41.25 NFS, respectively (Figure 4). Loges et al. (2008a), evaluating the production of a red and light pink torch ginger in a five years old clump, observed 109.66 and 68.00 flower stems per year, respectively, values above those observed in this experiment. It can be related to the clump age, once after the planting, the clumps pass through a period of development and establishment of the production (LOGES et al., 2008b). Ribeiro et al. (2012) assures that a torch ginger clump produces around 50 floral stems per year after the establishment. Hoult and Marcsik (2000) in Australia observed from 50 to 200 floral stems in four cultivars of torch ginger.

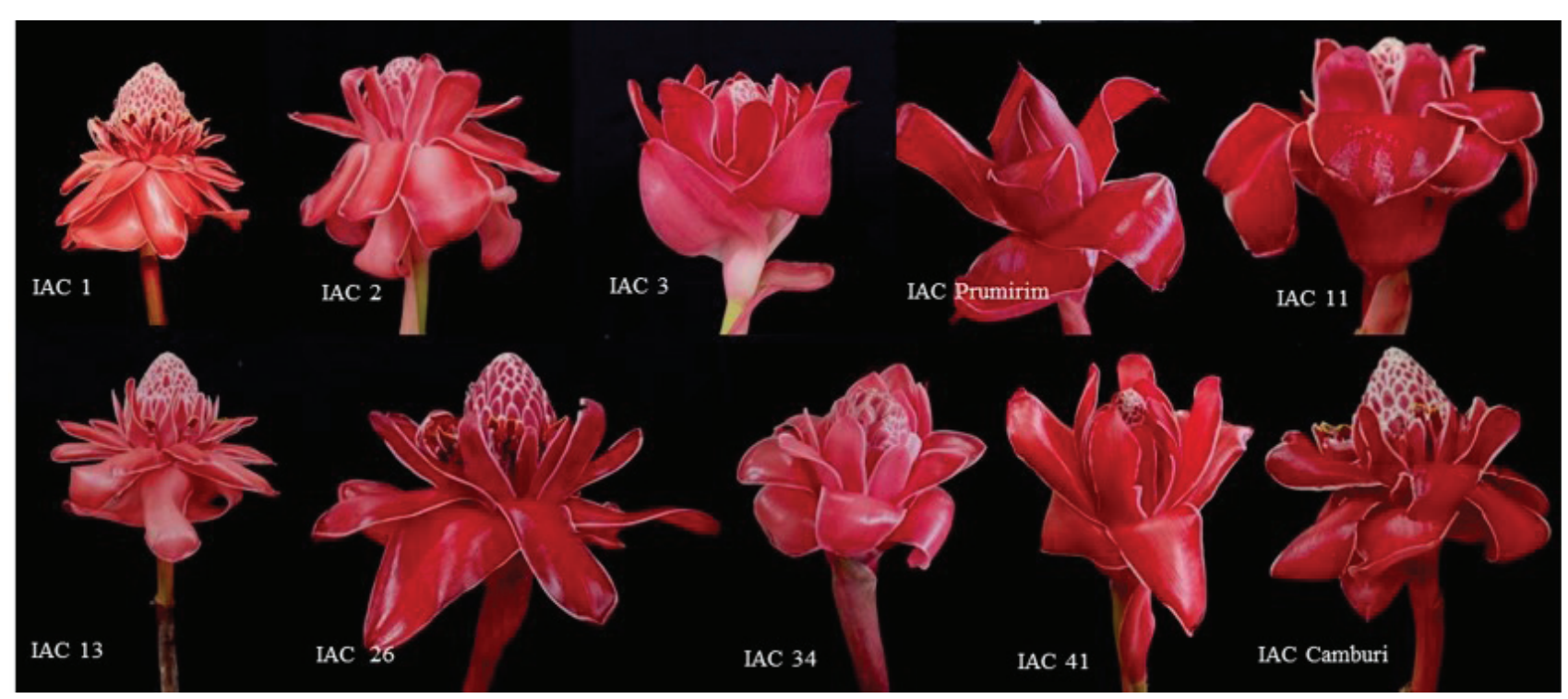

Figure 4. Ratio between the number of vegetative stems (NVS) and the number of floral stems (NFS) per clump, from May 2014 to December 2016, Paulista-PE.

According to Choon and Ding (2016), the growth of the torch ginger plant is divided into a vegetative phase, with the growth of the vegetative stem, and a reproductive phase, when the flower stem emerges from the rhizome. In the reproductive phase was observed the remobilization of photo-assimilates from the vegetative stem to develop the flower stem. It caused the vegetative stem to senesce from the basal part towards the apex and its tipping later. The authors affirm that in torch ginger plants one vegetative stem produces only one floral stem and the mechanisms that regulate the production of flower stems in torch ginger clumps have not been studied yet. In this experiment was observed higher NFS than vegetative stems (NVS) only in IAC Camburi 
and IAC 11, with ratio (r) of 1.2 and 1.07, respectively (Figure 4). The other genotypes showed higher NVS than NFS. IAC 3 presented the lowest ratio $(r=0.38)$, followed by IAC 1 , IAC 26, and IAC $34(r=0.44,0.41$ and 0.48 , respectively), indicating that further researches are needed to improve these ratios and to study the aspects that regulate flowering and senescence in torch ginger plants, as well.

Among the flower stem characteristics evaluated, only the inflorescence width (IW) showed a significant difference among the genotypes. The IAC 41 presented the largest IW with $15.93 \mathrm{~cm}$, while the IAC 1 presented the lowest with $7.31 \mathrm{~cm}$ (Table 3). Inflorescence length (IL) ranged from 12.57 (IAC 41) to 7.22 (IAC 1). Those characteristics are directly related to packaging and transportation processes. Very long and wide inflorescences are not appreciated as it may present friction between the bracts and impacts from the carton, causing mechanical damage and depreciation. Besides, it also reduces the amount (units / box) to be transported. Gonçalves et al. (2015) indicated that torch ginger ideal genotypes for cut flower should have inflorescence length between 12 to $14 \mathrm{~cm}$ and inflorescence width between 14 to $17 \mathrm{~cm}$. Nevertheless, the length and width of torch ginger inflorescence is associated with the maturation sequential development (CHOON and DING, 2016), and the market accepts different opening points (closed, semi-open or open) depending on the floral design and durability required.

Table 3. Characteristics of the flower stems of torch ginger (Etlingera elatior) genotypes evaluated from July 2016 to December 2016.

\begin{tabular}{|c|c|c|c|c|}
\hline & $1^{\text {st }}$ Sem. & $2^{\text {nd }}$ Sem. & $3^{\text {rd }}$ Sem. & $4^{\text {th }}$ Sem. \\
\hline Genotypes & 13 a 18 MAP & 19 A 24 MAP & 25 A 30 MAP & 31 a 36 MAP \\
\hline IAC 1 & $1.00 \mathrm{Aa}$ & $2.00 \mathrm{Aa}$ & $1.75 \mathrm{Aa}$ & $3.00 \mathrm{Aa}$ \\
\hline IAC 2 & $1.75 \mathrm{Aa}$ & $5.50 \mathrm{Aa}$ & $3.25 \mathrm{Aa}$ & $6.75 \mathrm{Aa}$ \\
\hline IAC 3 & $0.25 \mathrm{Aa}$ & $1.50 \mathrm{Aa}$ & $3.00 \mathrm{Aa}$ & $6.25 \mathrm{Aa}$ \\
\hline IAC 11 & 4.70Aa & $9.75 \mathrm{Aa}$ & $5.25 \mathrm{Aa}$ & $5.75 \mathrm{Aa}$ \\
\hline IAC 13 & $2.50 \mathrm{Aa}$ & $3.75 \mathrm{Aa}$ & $5.5 \mathrm{Aa}$ & $9.75 \mathrm{Aa}$ \\
\hline IAC 26 & $0.25 \mathrm{Aa}$ & $1.75 \mathrm{Aa}$ & $1.75 \mathrm{Aa}$ & 7.00Aa \\
\hline IAC 34 & $0.75 \mathrm{Aa}$ & $2.75 \mathrm{Aa}$ & $4.00 \mathrm{Aa}$ & $1.50 \mathrm{Aa}$ \\
\hline IAC 41 & $1.50 \mathrm{Ba}$ & 7.00ABa & $7.5 \mathrm{ABa}$ & $17.25 \mathrm{Aa}$ \\
\hline IAC Prumirim & $2.00 \mathrm{Aa}$ & 6.00Aa & $5.20 \mathrm{Aa}$ & $10.00 \mathrm{Aa}$ \\
\hline IAC Camburi & $6.00 \mathrm{Aa}$ & $13.00 \mathrm{Aa}$ & $9.25 \mathrm{Aa}$ & $12.75 \mathrm{Aa}$ \\
\hline
\end{tabular}

* Averages followed by the same horizontal capital letters do not differ from each other, (Tukey test)

** Averages followed by the same lowercase and vertical letters do not differ statistically from each other, (Scott-Nott's test)IL - comprimento da inflorescência (cm); IW - largura da inflorescência (cm); SL - comprimento da haste floral (cm); SD - diâmetro da haste floral (cm); FM - massa fresca (g); CICLE - período de desenvolvimento da emissão da haste floral até a colheita (dias); PHD - durabilidade pós-colheita (dias); AM - início da floração (meses); NFS - número de hastes florais e MP para 2015 e 2016 - (meses com produção $\geq 1$ haste floral, por ano).

Regarding to the floral stem length (SL), it should be approximately $80 \mathrm{~cm}$ for a better use by the florists, allowing them to make compact or taller arrangements, and this length was observed in all genotypes. Gonçalves et al. (2014), indicated ideal genotypes for cut flower should have SL between 100 to $128 \mathrm{~cm}$. The genotypes IAC 2, IAC 3, IAC 34, and IAC Camburi presented averages within that range $(118.30 ; 100.28 ; 116.22$ and $114.23 \mathrm{~cm}$, respectively). Loges et al. (2008a) and Choon and Ding (2016) observed that after the development of the inflorescence bud, there is no elongation of the floral stem and, if it does not have a commercial length, it may be removed from the clumps and discarded.

The IAC 3 was the only genotype that presented stem diameter (SD) smaller than $1 \mathrm{~cm}(0.87 \mathrm{~cm})$. In order to bear the inflorescence and prevent stem tipping, Loges et al. (2005) recommends a floral stem diameter of $1.00 \mathrm{~cm}$; and Gonçalves et al. (2014) between 1.30 and $1.65 \mathrm{~cm}$.
Nevertheless, it is not interesting to have very large stem diameters, once it is directly related to the final weight of the floral stem.

The fresh mass (FM) of the flower stem were between 140 and 277 for all genotypes. According to Gonçalves et al. (2014) despite, the great acceptability of torch ginger by the consumers, its commercialization is restricted due to the high weight of the flower stem. It may difficult harvesting, packing, and transportation processes, indicating FM between 166 to $236 \mathrm{~g}$. The genotypes IAC 1, IAC 2, and cultivar IAC Camburi showed the suggested range, but lighter floral stems should be selected.

The CYCLE, period between the floral stem emission until the harvest, ranged from 52 to 70 days. Gonçalves et al. (2014) observed genotypes with CYCLE ranging from 32 to 50 days. This characteristic is interesting to the producer, once it makes possible plan the forthcoming production, aiding in their sales. 
The postharvest durability (PHD) observed in IAC 41 was 8 days, followed by IAC 2, IAC 11, IAC 13 and IAC 26 that were 7 and 6 days, and less than 5 days in the other genotypes, including IAC Prumirim and IAC Camburi. Castro et al. (2013) observed PHD of 8 days for those cultivars. According to the literature the post-harvest durability varies widely. Hoult and Marcsik (2000) in Australia observed postharvest durability of 3 up to 10 days to four torch ginger cultivars and Choon and Ding (2013) observed 6 days.

Carneiro et al. (2014) concluded that the postharvest durability was correlated to the harvest point: only 4 days for the floral stems with open inflorescences and 10 days for floral stems with semi-open inflorescences. According to Choon and Ding (2017), when the true flowers of the torch ginger inflorescences start to open sequentially, the external bracts and the upper part of the peduncle begin to darken and dry, due to the reduction of soluble sugars and the degradation of the starch grains accumulated by the plant and used during the formation of the flowers. Thus, to guarantee the quality and durability of the flower stems, the inflorescences must be harvested before the flowers open, at the close or semi-open harvest points.

The PHD directly sets conditions for marketing flower stems. Floral stems with PHD longer than 10 days may be sent to distant locations and used longer-lasting events. However, floral stems with PHD shorter than eight days are restricted to sales in local markets and short-term events such as parties, a fact observed in the Recife-PE market.

Based on the score system proposed to select torch ginger genotypes as cut flowers (Table 4), it was observed that: IAC 26 and IAC 34 were classified as poorly adapted, presenting higher FM (237 g), NFS less than 19 and less than three months emitting floral stems in 2015 and 2016. IAC 1, IAC 2, IAC 3, IAC 11, AC 13 and IAC Prumirim received intermediate scores for most of the evaluated criteria and so were classified as adequate; IAC 41 and IAC Camburi, received maximum scores for most of the evaluated characteristics and so were classified as very suitable.

Table 4. Classification to suitability for using as cutting blossom of torch ginger genotypes (Etlingera elatior) from January 2015 to December 2016

\begin{tabular}{|c|c|c|c|c|c|c|c|c|c|c|c|c|c|}
\hline Genotypoes & IL & IW & SL & SD & FM & CYCLE & PHD & BF & NFS & $\begin{array}{c}\text { MP } \\
(15)\end{array}$ & $\begin{array}{c}\text { MP } \\
(16)\end{array}$ & Total & $\begin{array}{l}\text { Use as Cut } \\
\text { flower }\end{array}$ \\
\hline IAC 1 & 2 & 2 & 2 & 3 & 3 & 2 & 2 & 3 & 1 & 1 & 1 & 22 & Suitable \\
\hline IAC 2 & 2 & 2 & 3 & 3 & 3 & 1 & 2 & 2 & 1 & 1 & 2 & 22 & Suitable \\
\hline IAC 3 & 2 & 2 & 3 & 2 & 3 & 2 & 2 & 3 & 1 & 1 & 2 & 23 & Suitable \\
\hline IAC 11 & 2 & 2 & 2 & 3 & 3 & 1 & 2 & 3 & 2 & 3 & 2 & 25 & Suitable \\
\hline IAC 13 & 2 & 2 & 2 & 3 & 3 & 1 & 3 & 3 & 2 & 1 & 3 & 25 & Suitable \\
\hline IAC 26 & 2 & 3 & 2 & 3 & 1 & 1 & 2 & 3 & 1 & 1 & 2 & 21 & $\begin{array}{l}\text { Poorly } \\
\text { suitable }\end{array}$ \\
\hline IAC 34 & 2 & 2 & 3 & 3 & 1 & 2 & 2 & 2 & 1 & 1 & 1 & 20 & $\begin{array}{c}\text { Poorly } \\
\text { suitable }\end{array}$ \\
\hline IAC 41 & 3 & 3 & 2 & 3 & 1 & 1 & 3 & 3 & 3 & 2 & 3 & 27 & Very suitable \\
\hline IAC Prumirim & 2 & 2 & 2 & 3 & 3 & 1 & 2 & 3 & 2 & 2 & 3 & 25 & Suitable \\
\hline IAC Camburi & 2 & 2 & 3 & 3 & 3 & 1 & 2 & 3 & 3 & 3 & 3 & 28 & Very suitable \\
\hline
\end{tabular}

IL - inflorescence length; IW - inflorescence width; SL - floral stem length; SD - floral stem diameter; FM - fresh mass; CYCLE - development period from the emission of the floral stem to the harvest e PHD - post-harvest durability; BF - beginning of flowering; NFS - number of floral stems (2015 e 2016) and MP for 2015 and 2016 - (months with production $\geq 1$ floral stem, in the year).

\section{CONCLUSIONS}

It was possible to characterize torch ginger genotypes leading to the recommendation of IAC 41 and the IAC Camburi suitable for cut flower production in Zona da Mata of Pernambuco State, Brazil, area of the study.

\section{ACKNOWLEDGEMENTS}

We are thankful to the Mumbecas Farm, Tropical Flowers, Paulista, Pernambuco State, Brazil, the Agronomic Institute-IAC, the National Council of Scientific and Technological Development-CNPq, the Foundation of
Science and Technology Support of Pernambuco-FACEPE, and all that are part of Labflor - UFRPE Floriculture Laboratory.

\section{AUTHORS CONTRIBUTIONS}

P.G.P.A. D0000-0003-4680-3776: Planting of genotypes; character propose; evaluation of genotypes in the field; results discussion and scientific writing. J.C.C.A.F. (D0000-0002-9394-7935: Planting of genotypes; evaluation of genotypes in the field; and results discussion. S.S.L.S. D0000-0003-3101-4061: Planting of genotypes; evaluation of genotypes in the field; and results discussion. C.E.F.C. (D0000-0002-1407-0611: Results discussion and scientific 
writing. C.G. Doo00-0001-5414-0306: Results discussion and scientific writing. V.L. D0000-0001-9948-9501: Planting of genotypes; character propose; evaluation of genotypes in the field; results discussion and scientific writing.

\section{REFERENCES}

ALVARES, C.A.; STAPE, J.L.; SENTELHAS, P.C.; GONÇALVES, J.L.M.; SPAROVEK, G. Köppen's climate classification map for Brazil. Meteorologische Zeitschrift, v.22, n.6, p.711-728, 2013. DOI: 10.1127/09412948/2013/0507

CARNEIRO, D.N.M.; PAIVA, P.D.O.; CARNEIRO, L.F.; RODRIGUES, R.S.; LIMA, L.C.O.; DIAS, G.M.G.; PEDROSO, R.G.A.V. Developmental stage and pulsing in inflorescences of torch ginger. Ornamental Horticulture, v.20, n.2, p.163-170, 2014. DOI: https://doi.org/10.14295/ rbho.v20i2.578

CASTRO, C.E.F.; MOREIRA, S.R.; GONÇALVES, C.; CALANDRELLI, L.L. 'IAC Cacheffo': A new cultivar of torch ginger (Etlingera elatior (Jack) R.M. Sm. x E. hemisphaerica (B1.) R.M Sm.) selected by the Instituto Agronômico (IAC), Brazil. Heliconia Society, v.19, n.2, p.11, 2013.

CHAN, E.W.C.; LIM, Y.Y.; WONG, S.K. Phytochemistry and pharmacological properties of Etlingera elatior: a review. Pharmacognosy Journal, v.3, n.22, p.6-10, 2011. DOI: https://doi.org/10.5530/pj.2011.22.2

CHOON, S.Y.; DING, P. Sucrose affects postharvest characteristics of torch ginger (Etlingera elatior) inflorescence. Acta Horticulturae, v.1012, p.581-587, 2013. DOI: 10.17660/ActaHortic.2013.1012.78

CHOON, S.Y.; DING, P. Physiological changes of torch ginger (Etlingera elatior) inflorescence during development. HortScience, v.52, n.3, p.479-482, 2017. DOI: 10.21273/HORTSCI11189-16

CHOON, S.Y.; DING, P. Growth stages of torch ginger (Etlingera elatior) plant. Sains Malaysiana, v.45, n.4, p.507-515, 2016.

CRUZ, C.D. GENES - a software package for analysis in experimental statistics and quantitative genetics. Acta Scientiarum, v.35, n.3, p.271-276, 2013. DOI: http:// dx.doi.org/10.4025/actasciagron.v35i3.21251

GONÇAlves, C.; CASTRO, C.E.F.; COLOMBO, A.C. Divergência genética de Etlingera elatior baseada em características agromorfológicas para flores de corte. Revista Brasileira de Horticultura Ornamental, v.20, n.1, p.93102, 2014. DOI: 10.14295/rbho.v20i1.569
GONÇALVES, C.; AGUIAR, A.T.E.; CAPANEMA, L.M. Cultivares IAC. Boletim Técnico-Informativo do Instituto Agronômico. O agronômico, v.67, p.10-12, 2015.

HOULT, M.D.; MARCSIK, D. From rainforest to city florists: a breeding strategy for cut-flower gingers. Bulletin Heliconia Society International, v.10, n.1/2, p.8-11, 2000.

INMET- Instituto Nacional de Meteorologia. BDMEP - Banco de dados meteorológicos para ensino e pesquisa. Available in: <http://www.inmet.gov.br/portal/index. php? $\mathrm{r}=\mathrm{bdmep} / \mathrm{bdmep}>$, Accessed on: January 20 2017.

LOGES, V.; TEIXEIRA, M.C.F.; CASTRO, A.C.R.; COSTA, A.S. Colheita e pós-colheita de flores tropicais no estado de Pernambuco. Revista de Horticultura Brasileira, v.23, n.3, p.699-672, 2005. DOI: http://dx.doi. org/10.1590/S0102-05362005000300001

LOGES, V.; CASTRO, A.C.R.; COSTA, A.S.; GUIMARÃES, W.N.R.; TEXEIRA, M.C.F. Caracterização de hastes de flores tropicais da emissão até a colheita. Revista Brasileira de Horticultura Ornamental, v.14, p.91-98, 2008a. DOI: https://doi.org/10.14295/rbho. v14i1.236

LOGES, V.; COSTA, A.S.; GUIMARÃES, W.N.R.; TEIXEIRA, M.C.F. Potencial de mercado de bastão-doimperador e sorvetão. Revista Brasileira de Horticultura Ornamental, v.14, n.1, p.15-22, 2008b. DOI: 10.14295/ rbho.v14i1.225

NASCIMENTO, A.M.P.; PAIVA, P.D.O.; NERY, F.C.; SOUZA, R.R.; MANFREDINI, G.M.; ALMEIDA, E.F.A. Influência do espaçamento de plantio e luminosidade no desenvolvimento de bastão-do-imperador. Revista Brasileira de Ciências Agrárias, v.10, n.2, p.230-236, 2015. DOI: 10.5039/agraria.v10i2a5103

NASS, L.L.; PATERNIANI, E. Pre-breeding: a link between genetic resources and maize breeding. Scientia Agricola, v.57, p.581-587, 2000. DOI: http://dx.doi. org/10.1590/S0103-90162000000300035

RIBEIRO, T.R.; ALMEIDA, E.F.A.; FRAZAO, J.E.M.; CARVALHO, J.G.. Bastão-do-Imperador. In: PAIVA, P.D.O.; ALMEIDA, E.F.A. Produção de flores de corte. Lavras: Editora UFLA, 2012. p.90-103.

UNEMOTO, K.L.; FARIA, R.T.; ASSIS, A.M.; LONE, A.B.; YAMAMOTO, L.Y. Cultivo de bastão-do-imperador sob diferentes espaçamentos em clima subtropical. Ciência Rural, v.42, n.12, p.2153-2158, 2012. DOI: http://dx.doi. org/10.1590/S0103-84782012005000094.

VAREJÃO-SILVA, M.A. Meteorologia e Climatologia. Brasília: INMET, 2006. 449p. 